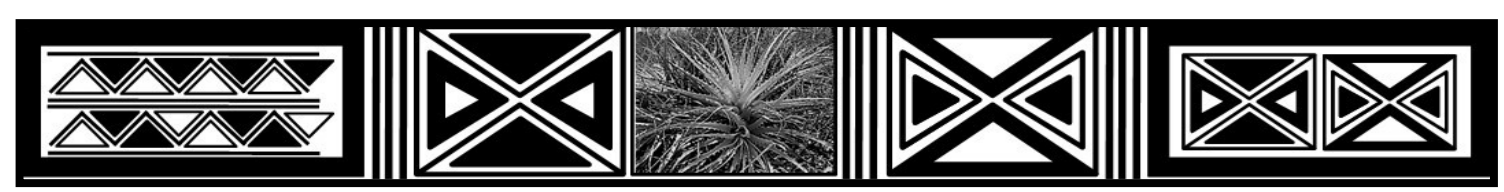

REVISTA MACAMBIRA

LABORATÓRIO DE POLÍTICAS PÚBLICAS, RURALIDADES E DESENVOLVIMENTO TERRITORIAL

Volume 3. Número 2. 2019. ISSN 2594 - 4754

ARTIGO / ARTICLE

DOI: https://doi.org/10.35642/rm.v3i2.265

\title{
SACRALIZAÇÃO E DEMONIZAÇÃO DA MULHER NO SÉCULO XX: SUA SEXUALIDADE EVIDENCIADA EM PRODUÇÕES INTERSEMIÓTICAS
}

\author{
SACRALIZATION AND DEMONIZATION OF WOMEN IN THE TWENTIETH \\ CENTURY: ITS EVIDENCED SEXUALITY IN INTERSEMIOTIC PRODUCTIONS
}

\section{Aline Maria da Conceição de Jesus \\ https://orcid.org/0000-0003-1450-6339}

Doutoranda pela Universidade Federal da Bahia (UFBA) em Língua e Cultura. E-mail: alininha sud@hotmail.com

\begin{abstract}
Recebido: 15 de abril de 2019
Aceito: 01 de outubro de 2019

RESUMO: Este artigo traz uma análise de diversas formas em que a mulher foi representada em produções intersemióticas durante o século XX. A pesquisa leva a uma reflexão no tocante à inquestionável emancipação feminina no campo da sexualidade. Contudo, será mostrado, aqui, o que podemos chamar de "efeitos colaterais" do processo de emancipação, o que causou certa demonização à figura feminina. O ser mulher será abordado, portanto, sob duas vertentes: a mulher sacralizada (prototípica) e a mulher demonizada (transgressora). Para tanto, será feita uma análise de um texto, publicado em meados do século XX, por Carlos Drummond de Andrade - Caso do Vestido - e o confrontaremos com outros textos como pinturas, fotografias, filmes e músicas.
\end{abstract}

PALAVRAS-CHAVE: Mulher. Sacralização. Demonização. Intersemiótica.

ABSTRACT: This article provides an analysis of the various ways in which women were represented in intersemiotic productions during the twentieth century. The research leads to a reflection on the unquestionable female emancipation in the field of sexuality. However, it will be shown here what we may call the "side effects" of the emancipation process, which caused some demonization of the female figure. The woman being will be approached, therefore, in two aspects: the sacralized woman (prototypical) and the demonized woman (transgressor). Therefore, an analysis of a text, published in the middle of the twentieth century, by Carlos Drummond de Andrade - Case of the Dress - will be made and we will confront it with other texts such as paintings, photographs, films and music.

KEYWORDS: Woman. Sacralization. Demonization. Intersemiotic. 


\section{INTRODUÇÃO}

Ao longo dos anos, a mulher vem sendo representada como um ser inferior ao homem, devendo estar sujeita às suas vontades e agir conforme o seu comando. Porém, ela vem se emancipando de forma cada vez mais abrangente e ocupando um espaço que sempre lhe pertenceu, mas que, até pouco tempo, era destinado apenas aos homens. Esse progresso se concretizou à custa de muitos sacrifícios e grandes batalhas travadas contra o preconceito de homens e até mesmo de muitas mulheres que, por terem se acostumado a viverem de acordo com os rigores de sua época, viam/veem a luta de outras como uma forma de desrespeito aos valores da sociedade a que pertenceram/pertencem.

Entretanto, no que diz respeito à sexualidade feminina, será que poderíamos afirmar que houve realmente emancipação? Ou será que o que houve, na verdade, foi uma degradação da figura feminina? A mulher prototípica, que era sacralizada, idealizada e divinizada até meados do século XX, está entrando em decadência ou tem sido demonizada por conta da liberdade que tem conquistado, sobretudo no que tange as questões sexuais?

\section{REPRESENTAÇÃO DA MULHER EM PRODUÇÕES INTERSEMIÓTICAS}

Historicamente, a mulher é representada como um ser sagrado e, ao mesmo tempo, profano. Bons exemplos desse antagonismo estão registrados no texto bíblico quando, por exemplo, Eva é colocada como uma vilã para boa parte do mundo cristão por ter sido ela quem ofereceu a Adão o chamado fruto proibido que os expulsou do paraíso e que, com isso, trouxe dor, sofrimento e morte ao mundo, de acordo com a crença de boa parte do Cristianismo. Adão é visto como o sujeito que foi influenciado negativamente por Eva e que, por isso, decaiu. Eva é, assim, um ser profano, degradante, corrompido e decaído, que trouxe o pecado ao mundo. A mulher que toma posição é, desde aí, demonizada.

Por outro lado, Maria, mãe de Jesus, é vista como um ser completamente puro, sacralizado, sem mácula, a ponto de poder trazer ao mundo o próprio Filho de Deus sendo ela ainda virgem. Maria é vista como a mulher prototípica, que, apesar de nenhuma mais poder alcançar tamanha santidade na Terra, deve ser tomada como exemplo a ser seguido e, inclusive, para boa parte do mundo cristão, deve ser adorada por homens e mulheres.

Contudo, apesar do antagonismo entre a mulher sacralizada e a demonizada, ambas sempre foram postas em condições inferiores às dos homens, que historicamente ocuparam 
os espaços de poder, relegando às mulheres papéis secundários e, na maioria dos casos, subalternos aos homens.

Importa salientar que as mulheres foram, também, ao longo dos séculos, retratadas em produções intersemióticas (poemas, pinturas, músicas, filmes, etc.) como sendo um ser sacralizado e profano; neste último caso estereotipado dessa maneira por fugir dos padrões estabelecidos da sociedade. A demonização da mulher esteve/está quase sempre atrelada ao fato de ela se desvincular do que a cultura machista impõe como modelo a ser seguido por uma "boa mulher", seja isso no âmbito do matrimônio, do ambiente de trabalho ou nos diversos espaços em que ela está inserida.

Analisar as mulheres por meio de uma abordagem intersemiótica é fundamentalmente importante para se entender as construções das identidades femininas não somente sob o viés literário, mas, sim, a partir das várias produções artísticas de que a sociedade dispõe.

A Semiótica é uma ciência formal que tem por objetivo estabelecer como devem ser todos os signos para uma inteligência capaz de aprender através da experiência. Deve, pois, conjugar dois aspectos para constituir-se: construir diagramas que lhe permitam explicitar as relações essenciais na constituição dos signos como pensamento e conferir como base para essa construção os elementos fundamentais com os quais se compõe o universo de toda e qualquer experiência. Deverão daí resultar as formas permitidas para a representação da realidade fenomênica (SILVEIRA, 2007).

A Semiótica, desenvolvida por Charles Peirce, tem por objeto de investigação todas as linguagens possíveis. O seu escopo são os modos de constituição de todo e qualquer fenômeno de produção de significação e de sentido. A intersemiótica consiste no estudo semiótico em diferentes meios ou linguagens. É com base nesse tipo de abordagem que este trabalho é desenvolvido.

\section{A MULHER EM O CASO DO VESTIDO}

O poema Caso do Vestido, de Carlos Drummond de Andrade, apesar de ter sido escrito em meados do século XX, e de, nessa época, a mulher já estar muito mais independente em relação à mulher do século anterior, retrata a submissão (quase que obrigatória) e a resignação da mulher frente à infidelidade do marido.

No poema, a esposa é colocada num patamar divino, sacro, que, mesmo sofrendo com a traição e desprezo de seu cônjuge, continua amando-o, dedicando-se a ele e 
cumprindo, rigorosamente, o papel que lhe foi imposto como único a ser contemplado: o de dona de casa. A mulher traída "entrega" seu marido à amante, demonstrando seu amor incondicional, seu zelo pelos "valores" almejados pela sociedade da época. Mesmo abandonada, continua cumprindo sua função de "rainha do lar", sendo, desse modo, um modelo a ser seguido por outras mulheres.

Por outro lado, a amante é colocada como destruidora do lar, um ser leviano e inconsequente, que rouba, sem piedade, o marido de outra tão somente para satisfazer seus desejos ou caprichos. Posteriormente, ela se apaixona por ele, mas, por se tornar, também, uma dona de casa, perdeu a graça e o homem que havia conquistado. Ela é quem agora é abandonada por ele, que retorna ao lar e é aceito, sem cerimônias, pela esposa.

Vejamos:

- Nossa mãe, o que é aquele vestido, naquele prego? - Minhas filhas, é o vestido de uma dona que passou [...] Era uma dona de longe, vosso pai enamorou-se. [...] me pediu que lhe pedisse, a essa dona tão perversa, que tivesse paciência e fosse dormir com ele...

Minhas filhas, procurei aquela mulher do demo. E lhe roguei que aplacasse de meu marido a vontade (DRUMMOND, 1945).

A mãe revela-se um ser pacífico e compreensivo, pois este era o seu papel, o seu destino natural como mãe, esposa e dona de casa exemplar. Pode-se perceber isso pela forma como ela se refere à infidelidade do marido às suas filhas e, também, pela maneira como aceita a aventura amorosa do seu companheiro.

O poema mostra a esposa como mulher ideal, dedicada ao lar e à família, que buscava, sobretudo, satisfazer as vontades do marido, agradando-o em todas as coisas, pois era esse o papel que lhe competia, essa deveria ser a sua felicidade. A esposa ideal deveria ser uma verdadeira "santa", amando sem medidas, fazendo sacrifícios que visassem, exclusivamente, a felicidade do amado.

Minhas filhas, procurei aquela mulher do demo. E the roguei que aplacasse de meu marido a vontade [...] Sai pensando na morte, mas a morte não chegava. Andei pelas cinco ruas, passei ponte, passei rio, visitei vossos parentes, não comia, não falava, tive uma febre terçã, mas a morte não chegava.

Fiquei fora de perigo, fiquei de cabeça branca, perdi meus dentes, meus olhos, costurei, lavei, fiz doce, minhas mãos se escalavraram, meus anéis se dispersaram, minha corrente de ouro pagou conta de farmácia (DRUMMOND, 1945). 
A boa esposa era a principal responsável pela paz doméstica e pela harmonia conjugal. Ainda que o marido a machuque, a agrida, isso é posto como algo natural e que a mulher precisa saber lidar, caso queira continuar casada.

E ficou tão transtornado, se perdeu tanto de nós, se afastou de toda vida, se fechou, se devorou, chorou no prato de carne, bebeu, brigou, me bateu, me deixou com vosso berço, foi para a dona de longe (DRUMMOND, 1945).

Dentre os trechos do poema que abordam ostensivamente a submissão da mulher ao homem, observemos:

- Minhas filhas, boca presa. Vosso pai evém chegando [...] - Nossa mãe, por que chorais? Nosso lenço vos cedemos.

- Minhas filhas, vosso pai chega ao pátio. Disfarcemos.

- Nossa mãe, não escutamos pisar de pé no degrau.

- Minhas filhas, eis que ouço vosso pai subindo a escada

(DRUMMOND, 1945).

Com a volta do marido, ela não se queixa, não discute, não cobra nada dele, apesar de todo sofrimento, necessidades, rejeição, humilhação e desprezo que passou. Agia como se nada tivesse acontecido:

[...] já na ponta da estrada vosso pai aparecia. Olhou pra mim em silêncio, mal reparou no vestido e disse apenas: - Mulher, põe mais um prato na mesa. Eu fiz, ele se assentou, comeu, limpou o suor, era sempre o mesmo homem, comia meio de lado e nem estava mais velho. O barulho da comida na boca, me acalentava, me dava uma grande paz, um sentimento esquisito de que tudo foi um sonho, vestido não há... nem nada

(DRUMMOND, 1945).

Já a mulher tida como leviana, mundana, fazia o possível para atrair, seduzir e satisfazer pela beleza e pelos apelos sexuais, era alvo das reprimendas impostas pela sociedade. A sua beleza e, precipuamente, o seu comportamento, era uma espécie de ameaças às regras estabelecidas e, desse modo, era uma afronta aos chamados bons costumes. Ela é representada como uma mulher provocante e inconsequente. Não se preocupa com nada, a não ser com a satisfação do seu próprio ego.

Eu não amo teu marido, me falou ela se rindo. 
Mas posso ficar com ele se a senhora fizer gosto, só pra lhe satisfazer, não por mim, não quero homem.

Olhei para vosso pai, os olhos dele pediam.

Olhei para a dona ruim, os olhos dela gozavam

(DRUMMOND, 1945).

Mais uma vez, a mulher apresentada como desvirtuosa é a perversa, é ela quem debocha, quem brinca com os sentimentos alheios. No entanto, no que se referia à felicidade, principalmente no casamento, era para ela impossível, uma vez que isso só era permitido às chamadas "moças de família". Ela acaba pagando pelo mal que havia feito ao ser desprezada pelo homem que um dia "roubou" e ao ser discriminada pela sociedade.

Um dia a dona soberba me aparece já sem nada, pobre, desfeita, mofina, com sua trouxa na mão. Dona, me disse baixinho, não te dou vosso marido, que não sei onde ele anda. Mas te dou este vestido, última peça de luxo que guardei como lembrança daquele dia de cobra, da maior humilhação. Eu não tinha amor por ele, ao depois amor pegou. Mas então ele enjoado confessou que só gostava de mim como eu era dantes

(DRUMMOND, 1945).

As mundanas faziam o possível e o que se achava impossível para arrastar os homens para si, eram consideradas artificiais e se utilizavam de recursos externos como trajes da moda e muitos cosméticos, possuíam, também, um comportamento corporal, utilizando de poses e gestos que se configuravam em apelos sexuais através da aparência, mas que, por conta da artificialidade destes, acabavam sem atrativos e sem mistérios.

Olhei para a cara dela, quede os olhos cintilantes? quede graça de sorriso, quede colo de camélia? quede aquela cinturinha delgada como jeitosa? quede pezinhos calçados com sandálias de cetim? (DRUMMOND, 1945).

A chamada mulher livre era marginalizada pela sociedade por "causar grandes prejuízos" à instituição mais requisitada ainda até aquela época: o casamento. Ela foi adjetivada como prostituta, leviana, mundana, demônio. Podemos observar isso nos seguintes trechos:

Minhas filhas, procurei aquela mulher do demo [...] O seu vestido de renda, de colo mui devassado, mais mostrava que escondia as partes da pecadora

(DRUMMOND, 1945). 
A mulher ideal era aquela considerada uma boa dona de casa, que consistia basicamente em ser uma exímia esposa e mãe dedicada. A esposa ideal satisfazia o seu marido e o complementava no cotidiano doméstico, pois o seu bom desempenho erótico não fazia parte das expectativas da sociedade, quase que a anulando nesse sentido, isso porque sua sexualidade era restringida ao casamento, ao passo que a sociedade permitia as experiências sexuais aos homens.

Assim, ao considerar a traição como um ato natural ou irrelevante se praticada por um homem, a "boa" esposa, que devia ser tolerante e paciente, era a companheira ideal, sacralizada. Já a amante, era uma libertina, dada aos prazeres e vivia apenas para ceder aos prazeres do homem, tornando-se, também, um objeto, mais uma para ser manipulada e usada até que os homens enjoem e busquem novas aventuras.

É importante ressaltar que o homem não é culpado em momento algum pelas duas atitudes. É a mulher amante que o seduz, que o atrai, que se utiliza de artifícios para fisgar e "tomar" o marido da outra. Apesar de ele ser o centro das atitudes negativas com ambas as mulheres, mesmo tendo sido ele quem abandonou as duas, quem as traiu e humilhou, ele é colocado como vítima da sedução e, quando se refere a ambas as mulheres, do desleixo delas, que o fez buscar novidades fora.

O poema revela a coisificação do ser feminino na relação homem e mulher, bem como revela como tanto as mulheres prototípicas como as que fugiam aos padrões estabelecidos pela sociedade sofriam diante de um patriarcalismo que imperava e que punha o homem num patamar sempre muito mais elevado do que a mulher.

\section{A MULHER NO SÉCULO XX EM OBRAS CINEMATOGRÁFICAS}

Baseado no conto que acaba de ser analisado, foi produzido um filme - O Vestido (FIGURA 1 A) - e, neste, apesar de ser uma produção muito moderna, não são evidenciados quaisquer esforços para que a visão ideológica de que a mulher afeiçoada aos prazeres da carne não tem direito à felicidade fosse quebrada. Verifica-se também que, na mesma proporção, nada é feito para que a mulher submissa, devota e resignada tenha uma felicidade dentro ou fora dos laços do matrimônio, apesar de lhe surgirem oportunidades. 
Figura 1 - A) Capa do filme O Vestido; B) Capa do filme O Sorriso de Monalisa; C) Capa do filme Terra Fria.
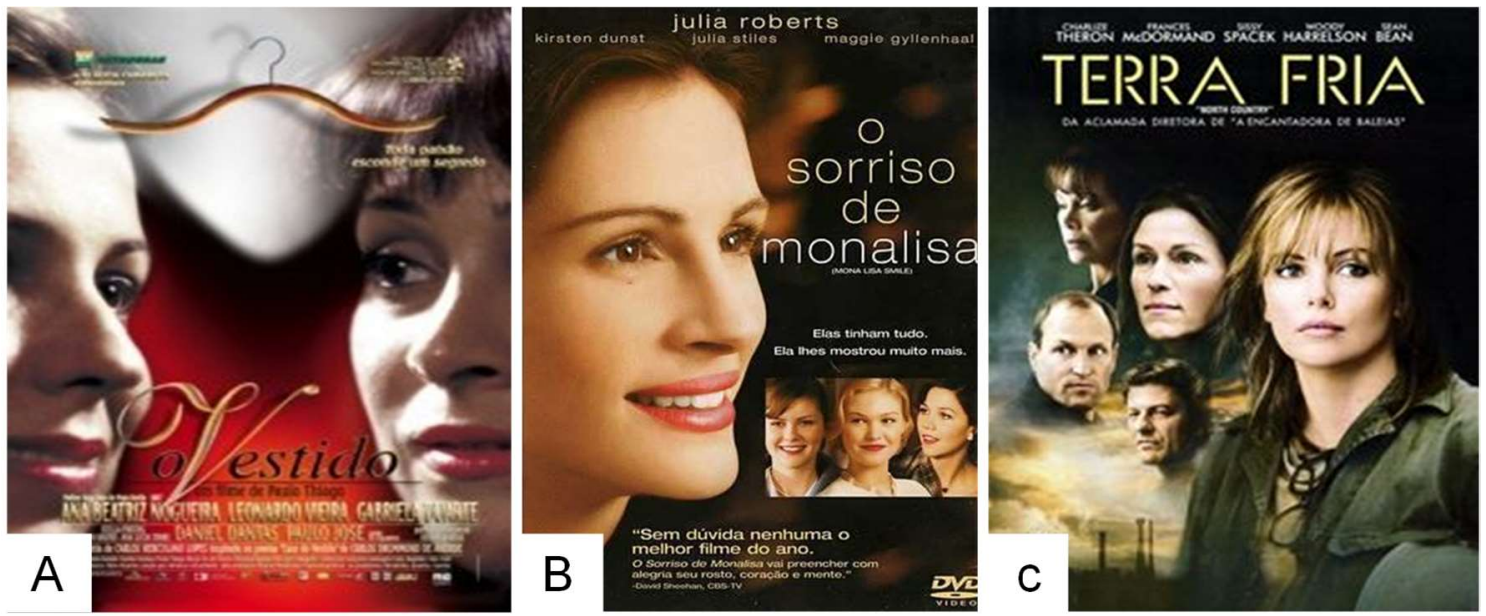

Fonte: A) https://filmow.com/o-vestido-t5853/; B) https://produto.mercadolivre.com.br/MLB707762796-dvd-filme-o-sorriso-de-monalisa-c-julia-roberts-dublado-JM; http://www.adorocinema.com/filmes/filme-56284/

Já em O Sorriso de Monalisa (FIGURA 1 B), filme que recria a atmosfera dos costumes do início da década de 50, conta a história de uma professora de arte que estudou numa universidade liberal e teve que enfrentar uma escola feminina tradicionalista onde as melhores e mais brilhantes jovens mulheres dos Estados Unidos recebem uma educação dispendiosa para se transformarem em cultas esposas e responsáveis mães.

No filme, a professora tenta levar suas alunas a pensarem de forma liberal, enfrentando a administração da escola e as próprias garotas, pois não há por parte destas algo além do desejo de se tornarem futuras esposas dedicadas e preparadas para transformar a vida de seus maridos numa existência confortável, em que as aparências são mantidas a qualquer custo (ainda que isso signifique o sacrifício de suas honras e esperanças).

O Sorriso de Monalisa é, portanto, um libelo em favor da emancipação das mulheres em todos os setores, sobretudo no tocante à sexualidade, e uma pesada crítica ao conformismo que imperava entre as representantes do sexo feminino da época.

Terra Fria (FIGURA 1 C), por sua vez, é um filme baseado em uma história desconfortavelmente verdadeira de Josey Aimes, uma mulher que quebrou a barreira da discriminação de gênero ao trabalhar numa insalubre mina de ferro de Minesota. Além de perpassar, também, as barreiras legais, movendo a primeira ação trabalhista por assédio sexual na nação norte-americana.

Nas obras cinematográficas analisadas (Figura 1), a mulher é representada, em alguns casos, com uma leve tentativa de romper com os padrões estéticos e morais estabelecidos pelos critérios convencionais que circundavam a vida das pessoas na época. Porém, essa 
tentativa ainda não é muito valorizada, mesmo em tempos modernos, pois é vista através de olhares preconceituosos e discriminatórios por culturas demasiadamente machistas compostas por homens e mulheres que, em vez de emancipação e liberdade, nutrem uma excessiva depreciação da figura feminina.

\section{A MULHER REPRESENTADA EM PINTURAS E PROPAGANDAS}

Pode-se observar que foi por meio de esforços árduos que a mulher conseguiu se emancipar, sobretudo no campo profissional, pois era feita uma frequente associação entre a mulher no trabalho e a moralidade sexual. No discurso de diversos setores sociais, destacase a ameaça à honra feminina representada pelo mundo do trabalho. O lugar onde trabalham é descrito pela sociedade como "antro de perdição", "bordel”, enfim, um lugar onde a mulher não deveria estar, ou que, pelo menos, "mulher de bem" não estaria nunca. E as mais prejudicadas e discriminadas eram as mulheres pobres:

A mulher pobre, cercada por uma moralidade oficial completamente desligada de sua realidade, vivia entre a cruz e a espada. O salário minguado e regular de seu marido chegaria a suprir as necessidades domésticas só por um milagre. Mas a dona de casa, que tentava escapar à miséria por seu próprio trabalho, arriscava sofrer o pejo da "mulher pública". Em vez de ser admirada por ser "boa trabalhadora", como o homem em situação parecida, a mulher com trabalho assalariado tinha de defender sua reputação contra a poluição moral, uma vez que o assédio sexual era lendário (PRIORE, 2004, p. 433).

Di Cavalcanti produz a obra a seguir (Figura 2) baseada na realidade dessas mulheres:

Figura 2 - Imagem de mulher pobre, produzida por Di Cavalcanti

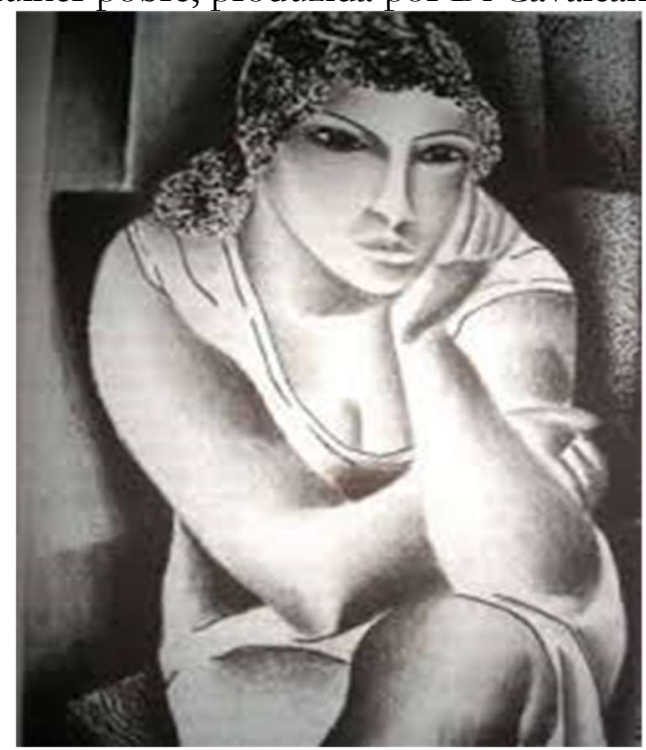

Fonte: Coleção Mário de Andrade: artes plásticas. São Paulo: IEB/USP, 1984. p. 76. 
A mulher pobre, que se via em meio a uma moralidade oficial que se deslocava completamente de sua realidade, vivia constantemente um "dilema imposto pela necessidade de escapar à miséria com o seu trabalho e o risco de ser chamada de "mulher pública" (PRIORE, 2006, p. 519).

A propaganda é outro meio que retrata bem a preocupação das moças com o casamento como pré-requisito para alcançar a plena felicidade, o não casar significava fracasso. Deste modo, era permitido utilizar artifícios pouco explícitos para atrair o pretendente, como: estimular sua vaidade, estar sempre de bom humor, vestir-se bem e elogiar o seu trabalho, a fim de conquistar seu pretendente.

Observemos essa representação (Figura 3) na propaganda a seguir:

Figura 3 - Imagem de mulher em quadrinhos

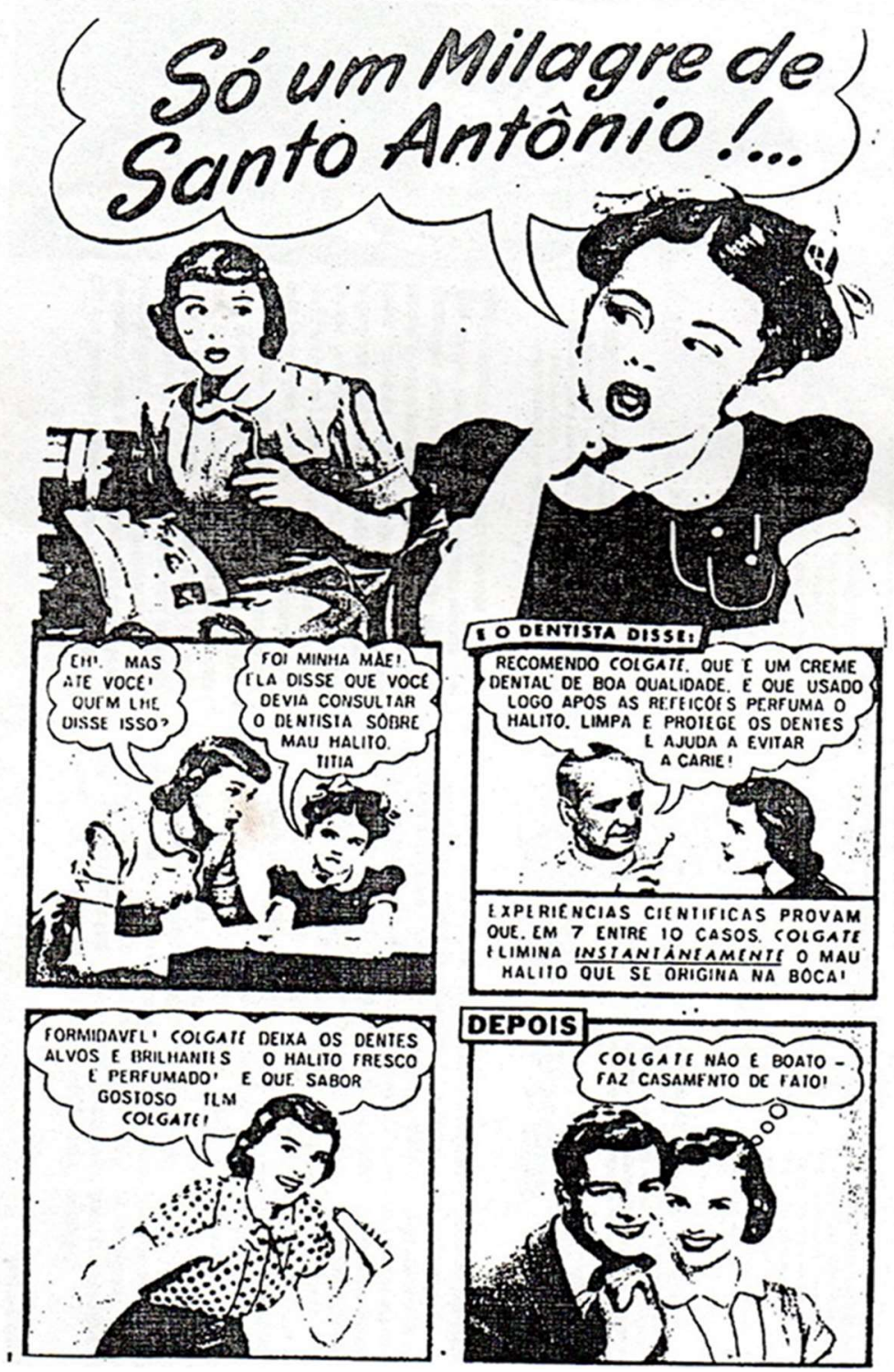

Fonte: Querida. Rio de Janeiro: Rio Gráfica, 1958. ano v, n. 06, p. 73 


\section{Sacralização e demonização da mulher no século XX: sua sexualidade evidenciada em ...}

A matéria da revista Nova (Figura 4), de novembro de 1994, mostra, em contraponto às revistas da década de 40, 50 e 60, a temática do sexo abordada de forma ousada logo em sua capa. Por meio das chamadas "Os 8 hábitos da mulher que adora sexo" e "Casada com um, fazendo sexo com outro. O campo minado de muitos casamentos", bem como da atriz Luiza Brunet, símbolo sexual no Brasil durante a década de 90, revelando o corpo através de decote e vestido demasiadamente ousado, se comparado com as vestimentas das décadas anteriores, a revista revela a liberdade sexual feminina da mulher do final do século XX. Chamadas de capa e matérias com tal conteúdo eram inconcebíveis em revistas de meados do século XX.

Figura 4 - Imagem que evidencia a liberdade sexual da mulher do final do século XX.

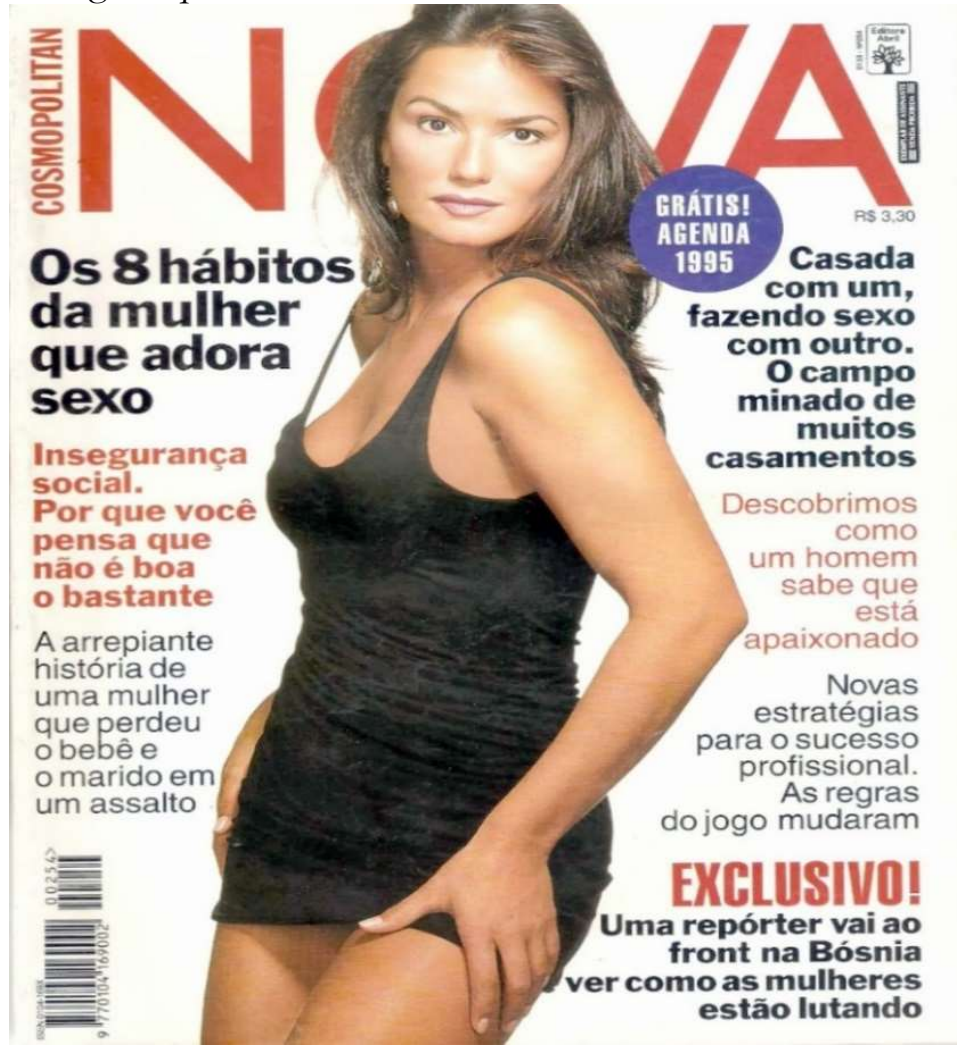

Fonte: Acervo galerias Revista Nova

Ao fazer uma comparação entre pinturas e propagandas, pode-se perceber a valorização que era dada ao casamento ou ao fato de a mulher ser casada. A mulher da elite dificilmente permanecia solteira, pois o matrimônio era, na maioria dos casos, realizado por interesse e o amor era o que menos importava até o início do século passado. Vale ressaltar, também, que, após casada, a esposa jamais poderia deixar o marido, independentemente do motivo dado por ele.

A mulher era frequentemente representada nas pinturas e propagandas a partir do viés que era vista na sociedade, mulheres ricas, pobres, negras, brancas, casadas, solteiras, 
sempre de um modo estereotipado, com forte carga de preconceito. Era colocada quase sempre (para não dizer sempre) em posição inferior ao homem, e este ocupava posição de destaque e num patamar de superioridade em relação a ela. Isso pode ser observado na imagem a seguir.

Figura 5 - Imagem de mulher do final do século XIX.

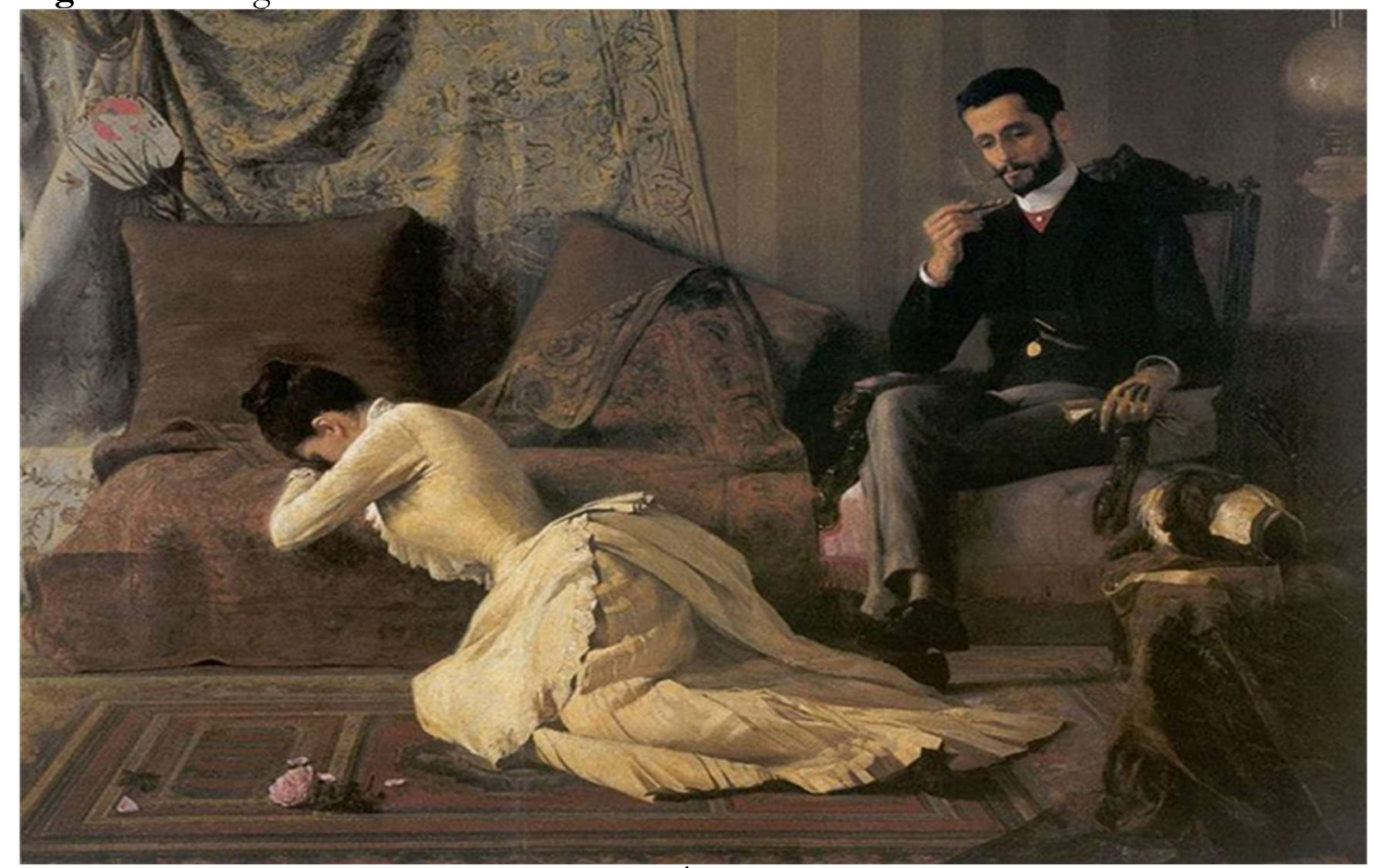

Fonte: Arrufos, Belmiro de Almeida, 1887. Óleo sobre tela, 89 x116 cm. Rio de Janeiro, Museu Nacional de Belas Artes.

A pintura Arrufos (1887), de Belmiro de Almeida, mostra uma mulher e um homem em um ambiente muito parecido com o interior de uma residência. A cena revela um desentendimento entre o casal, porém o homem permanece calmo, controlado, retratando a natureza mais fria do homem ou seu egocentrismo. Já a mulher é mostrada como um ser cheio de emoções, o que é percebido pela maneira como está ao chão, aparentemente em lágrimas, revelando sua natureza vista como passiva e frágil.

Outro ponto a ser destacado é que a mulher, que ocupa a posição central e inferior da imagem, está de joelhos no chão, mãos no rosto e apoiada com os braços em um sofá, ao passo que o homem é posto numa posição superior e olhando para o charuto, como se para ele pouco importasse o que a mulher estava sentindo. A localização da mulher na parte inferior da imagem revela a posição em que a sociedade a colocava, numa condição inferior ao homem. Do mesmo modo, o homem, colocado num plano superior, ocupa uma posição de superioridade em relação à mulher, e essa era a maneira como a sociedade o via e o tratava. 
Apesar de ser do final do século XIX, essa pintura é adequada neste artigo por mostrar como a mulher se portava no início do século XX.

Observa-se, então, que a mulher era retratada sob os mais diferentes aspectos e das mais diferentes maneiras. As pinturas e propagandas se tornaram importantes instrumentos de caracterização do ser feminino. Por meio dessas artes, a mulher era representada sob as suas mais diversas faces.

\section{A MULHER REPRESENTADA NA MÚSICA}

A música é outra forma de produção intersemiótica em que a figura feminina é tema. Através de uma canção da década de 40 e outra do ano 2000, é possível notar algumas das representações da mulher no decorrer do século XX. Tais músicas foram escolhidas por revelarem, notadamente, a mulher em suas diferentes faces.

“Amélia não tinha a menor vaidade/ Amélia que era a mulher de verdade [...]”. Quem nunca ouviu esses versos? Esse é o refrão de um dos maiores clássicos da música brasileira, composta em 1942, por Mário Lago e Ataulfo Alves, Ai, que saudade da Amélia.

A música trata de uma personagem do gênero masculino que, desiludido com um certo amor, diz que está com saudade de Amélia, um antigo amor. A sua atual companheira é exigente, sem consciência e maltrata "o pobre rapaz". A atual companheira só quer luxo e riqueza. Amélia não. Essa era capaz de passar fome e ainda de achar bonito não ter o que comer. Sim, Amélia é que era a mulher de verdade, até porque não tinha a menor vaidade, elemento dispensável para uma boa esposa.

Observemos a letra da canção:

Ai, que Saudade da Amélia

Nunca vi fazer tanta exigência

Nem fazer o que você me faz

Você não sabe o que é consciência

Não vê que eu sou um pobre rapaz

Você só pensa em luxo e riqueza

Tudo o que você vê, você quer

Ai, meu Deus, que saudade da Amélia

Aquilo, sim, que era mulher

Às vezes passava fome ao meu lado

$\mathrm{E}$ achava bonito não ter o que comer

E quando me via contrariado dizia:

Meu filho, o que se há de fazer

Amélia não tinha a menor vaidade

Amélia que era a mulher de verdade

(ALVES; LAGO, 1942) 
A personagem principal retratada na composição é uma mulher subordinada ao homem, num relacionamento evidenciado por marcadas relações de poder. Ela descreve a mulher ideal, uma mulher que vive em função do marido e que desempenha o papel de sua empregada doméstica não remunerada.

“Às vezes passava fome ao meu lado/ E achava bonito não ter o que comer", ou seja, Amélia fazia de tudo para não deixar o homem contrariado, era extremamente compreensiva e não se dava a vaidades. Amélia é uma mulher sacralizada, do lar, o modelo de mulher para se ter dentro de casa, segundo os preceitos da sociedade. Ainda hoje, embora as mulheres já tenham obtidos grandes conquistas no tocante à igualdade de gêneros, Amélia é tida por muitos como a mulher prototípica, a mulher ideal para casar e para um homem constituir família.

A mulher que aparece em segundo plano é alguém que faz muita exigência, que "não sabe o que é consciência", que "só pensa em luxo e riqueza" e tudo o que vê, quer. Ou seja, ela foge ao padrão estabelecido de mulher dominada. É ela quem tem a atitude de querer luxo e riqueza, que quer sempre mais, que não se satisfaz com o que lhe é oferecido pelo marido. De certo modo, é ela quem domina. A mulher exigente se contrapõe a Amélia, que fazia de tudo para não desagradar ao marido, que, inclusive, "achava bonito não ter o que comer". A mulher exigente pode ser agora a Amélia emancipada, que encontrou sua liberdade, que percebeu que pode querer mais da vida e do marido, que não se conforma mais com a vida doméstica e sem vaidades.

É possível inferir que o homem sente falta da Amélia de antes, sem vaidades, sem exigências, não sendo livre e independente dele e das suas vontades. Nota-se que a mulher exigente é a culpada por todo o infortúnio "do pobre rapaz”. Mais uma vez, o antagonismo entre a mulher sacralizada e a mulher demonizada fica evidente. Uma, a ideal, foi a responsável pela paz e tranquilidade que o homem teve um dia, a outra, a que foge dos padrões impostos, é a que traz intranquilidade e desilusão ao homem que não aguenta tanta exigência. A mulher sacralizada e a demonizada pode ser a mesma mulher em momentos diferentes da vida. Assim, a música, também, pode ser intitulada, implicitamente, da seguinte maneira: Ai, que saudade [daquela] Amélia.

Já na composição musical O Baile Todo, do ano 2000, de autoria de Carlos Lago Da Costa, Umberto Da Silva Tavares, Victor De Brito Junior, Leandro Dionizio Dos Santos e Anslem Douglas, a figura feminina revela-se de outra maneira. Nesta obra, a mulher é descrita como um ser desprovido de raciocínio, valor, vontade própria, enfim, ela é mostrada como um animal. Em seus versos é notório o cunho eminentemente sexual. 


\author{
O Baile Todo \\ Só as cachorras \\ As preparadas \\ As popozudas \\ O baile todo \\ Pula sai do chão \\ Esse o bonde do tigrão \\ Libera a energia \\ E vem pro meio do salão \\ O baile está tomado \\ Eu quero ver você dançar \\ Tá tudo dominado \\ E o planeta vai gritar \\ Vou provar que sou tigrão \\ Vou te dar muita pressão \\ Quando vejo um popozão \\ Rebolando no salão \\ Não consigo respirar \\ Fico louco para pegar \\ Melhor tu se preparar \\ Que o tigrão vai te ensinar \\ Agora é ruim de tu fugir \\ Que o tigrão vai te engolir \\ Se tu corre por aqui \\ Eu te pego logo ali \\ Eu vou lutar até o fim \\ Vou trazer você pra mim \\ Eu te chamo bem assim \\ Só as cachorras \\ As preparadas \\ As popozudas \\ O baile todo
}

A letra da música, composta por homens, revela o machismo do homem na definição da mulher. Eles definem a mulher frequentadora do baile funk de três maneiras distintas. As cachorras, que são as mulheres vistas como "vadias" novas. As preparadas são aquelas que estão prontas para realizarem o ato sexual, muitas frequentadoras de baile funk vão à festa sem as peças íntimas. As popozudas são as mulheres que possuem as nádegas avantajadas, assumindo essa parte do corpo feminino uma função de cunho sexual. É uma zona erógena, na qual há muito investimento por parte de várias mulheres, a fim de atrair quem elas desejam seduzir.

"Fico louco para pegar/ Melhor tu se preparar/ Que o tigrão vai te ensinar/ Agora é ruim de tu fugir/ Que o tigrão vai te engolir". Nesse trecho, marca-se o domínio do homem sobre a mulher, mais uma vez. Ele se coloca como animal, um verdadeiro tigre, que envolveria sua vítima até que não lhe sobrasse chance de defesa e a "engolisse", o que faz lembrar o termo bastante usado por muitos homens quando, referindo-se ao ato sexual, dizem que comerão uma 
mulher, reduzindo-a, metaforicamente, a um pedaço de carne que serve para satisfazer os desejos do seu "predador", o homem.

A mulher, por sua vez, é mostrada como um ser que aparece para ser “degustada”. É ela quem acaba recebendo a culpa por se insinuarem, como as cachorras; por se oferecerem explicitamente (as preparadas); e por instigarem o "lado animal" do homem com suas ancas largas, as popozudas.

Essas mulheres são vistas pela sociedade de modo negativo, e isso se deve à questão histórica que padroniza o comportamento feminino, pondo as mulheres que se assemelham aos homens no sentido de serem livres sexualmente, ao contrário dos rótulos dados a eles (a exemplo do rótulo de garanhão), como mulheres fáceis, "mulheres da vida", mulheres nas quais não se pode confiar.

A demonização de mulheres que adotam o estilo de vida mais livre é feita até mesmo, e, em muitos casos, principalmente, por outras mulheres, que consideram determinados tipos de comportamento inadequados para mulher, sobretudo no âmbito da sexualidade, e adequados para homens.

\section{CONSIDERAÇÕES FINAIS}

A rigidez social, característica do início do século XX, fazia com que a caracterização do ser feminino representado em obras intersemióticas fosse vista sob dois vieses, mas de um modo muito uniforme: ora pura (com ar angelical), ora pecadora (profana). Percebemos esses resquícios ainda na sociedade atual, em pleno século XXI. É muito claro que velhos paradigmas ainda não foram desconstruídos, e custarão a ser.

A emancipação da mulher no sentido sexual e em outros aspectos é realmente algo incontestável, como pôde ser observado nos vários aspectos abordados neste artigo. Contudo, tal liberdade conquistada ainda é vista por homens, e mesmo por mulheres, de forma pejorativa. Para muitos, a liberdade obtida é sinônimo de degradação da mulher, configura-se num declínio da figura feminina e, por isso, ela é demonizada.

Não se pode esquecer que, como em todas as obras analisadas, as identidades femininas são construções majoritariamente masculinas. Logo, no século XX, a mulher ainda não coloca a própria percepção de sua condição social, sexual e individual. É o homem quem faz isso. É ele quem representa a mulher. A voz feminina continua sendo silenciada e, com isso, ganha valorização a mulher ideal do ponto de vista masculino, a mulher submissa, que lhe cede todas as vontades, e é demonizada a mulher que não se configura como a adequada para ele, aquela que é oposição à mulher sacra. 
A mulher (e o homem) do século XX continua influenciando, substancialmente, a formação da identidade da mulher atual. A problemática que envolve a mulher santa/demoníaca, no campo da sexualidade, está ligada a coerções e à modalidade do social. O corpo feminino é, portanto, composto de fibras culturais que lhe conferem formas, ora de um ser angelical, ora de um ser demoníaco. Ora uma Maria (santa), ora uma Eva (transgressora).

\section{REFERÊNCIAS}

ALMEIDA, Belmiro de. Arrufos. 1887. Óleo sobre tela, 89 x116 cm. Rio de Janeiro, Museu Nacional de Belas Artes.

ANDRADE, Carlos Drummond de. Caso do Vestido. In: A Rosa do Povo. $10^{a}$ Ed. Rio de Janeiro: Record, 1991.

ALVES, Ataulfo; LAGO, Mário. Ai, que saudades da Amélia. Rio de Janeiro: Odeon, 1942. Disco 48 RPM.

BERNARDI, Francisco. As bases da literatura brasileira. Porto Alegre: AGE, 1999. BONDE DO TIGRÃO. O baile todo. Rio de Janeiro: Sony music, 2001.

CAVALCANTI, Di. Mulher sentada com a mão no queixo, s.d., Di Cavalcanti. In: Marta Rossetti Batista, Yone Soares de Lima (org.). Coleção Mário de Andrade: artes plásticas. São Paulo: IEB/USP, 1984. p. 76.

DEL PRIORE, Mary. História das mulheres no Brasil. São Paulo: Contexto, 2004. História do amor no Brasil. São Paulo: Contexto, 2006.

ECO, Umberto. Semiótica e filosofia da linguagem. Trad. Maria Rosaria Fabris e José Luiz Fiorin. São Paulo: Ática, 1991. Série Fundamentos.

JUNIOR, Benjamim Abdala; CAMPEDELLI, Samira Youssef. Tempos da literatura brasileira. São Paulo: Ática, 1999.

NICOLA, José de. Literatura Brasileira: das origens aos nossos dias. $6^{\text {a }}$ Ed. São Paulo: Scipione, 1993.

NOVA. n² 254, 1994. Disponível em: < https://muzeez.com.br/galerias/revista-novaanos-90/xbEDwXguk8fY5RXw8>. Acesso em: 10 abr. 2019.

O SORRISO DE MONALISA. Direção: Mike Newell. Produção: Fredward Johanson. Estados Unidos, 2003, 1 DVD (114 min.).

O VESTIDO. Direção: Paulo Thiago. Produção: Vitória Produções cinematográficas. Brasil, 2004,1 DVD (121 min.).

PEIRCE, Charles Sanders. Semiótica. Tradução de José Teixeira Coelho Neto. São Paulo: Perspectiva, 2000. 
QUERIDA. Propaganda do creme dental Colgate. Rio de Janeiro: Rio Gráfica, 1958. ano v, n. 06, p. 73.

SILVEIRA, L. F. B. Curso de Semiótica Geral. São Paulo: Quartier latin, 2007.

TERRA FRIA. Direção: Niki Caro. Produção: Jeff Skoll. Estados Unidos, 1 DVD (126 min.). 